\title{
The Role of Small and Medium Enterprises in Alleviating the Development Challenges Facing South Africa
}

\author{
Olawale Fatoki \\ Department of Business Management, Turfloop campus, University of Limpopo, Limpopo Province, South Africa \\ Email: Olawale.fatoki@ul.ac.za
}

\section{Doi:10.5901/mjss.2014.v5n23p270}

\begin{abstract}
The study highlighted some of the development challenges facing South Africa. These include high levels of unemployment, poverty and income inequality. The objective of the study is to examine the critical role that small and medium enterprises (SMEs) play in alleviating some of the development challenges facing South Africa. SMEs are expected to be an important vehicle to address the challenges of job creation, sustainable economic growth, equitable distribution of income and the overall stimulation of economic development in South Africa. The study finds that the perception of entrepreneurial opportunities and capabilities has increased since 2001 but still relatively low by international standard. In addition, the rate of business establishment is much lower than the rate of discontinuance. There is a net loss of small businesses. These factors may negatively impact on the ability of SMEs to help in alleviating some of the development challenges facing South Africa. Policy measures to improve the low rate of business establishment and reduce the high rate of discontinuance are of critical and urgent importance in South Africa.
\end{abstract}

Keywords: role, small and medium enterprises, development challenges, South Africa

\section{Introduction}

South Africa faces some development challenges. These include high levels of unemployment, poverty, income inequality, crime and corruption. Statistics South Africa (2014) estimated the unemployment rate of South Africa to be $25.2 \%$. Young people especially are vulnerable in the labour market. South Africa has the third highest unemployment rate in the world for people between the ages of 15 to 24 . More than $50 \%$ of young South Africans between 15 and 24 areunemployed (Global Risk, 2014). In addition, women experience a higher level of unemployment than men in South Africa. The unemployment rate of women is $2.9 \%$ higher than the national average (Statistics South Africa, 2010). Between the first quarter of 2013 and the first quarter of 2014, the number of unemployed women increased by 134000 (or 5.8\%) while the number of unemployed men increased by 71000 (or 2.8\%) (Statistics South Africa, 2014).

The poverty level in the South Africa has declined since 2006. However, poverty level is still relatively high despite the fact that the number of people living below the poverty line has dropped. While the poverty situation has seen some improvement, inequality however remains a major challenge. The Gini coefficient is approximately 0.65 based on expenditure data and 0.69 based on income data (2011 figures). This is one of the highest levels of inequality in the world (Statistics South Africa, 2014). Furthermore, youth poverty is very high in South Africa. About $65.1 \%$ of children live in households that fall into the bottom two income quintiles and that have a per capita income of less than R650 a month (Statistics South Africa, 2010). Female poverty is higher than male poverty in South Africa. Shisana et al. (2010) note that the feminisation of poverty has become apparent in South Africa.

Some of the other development challenges faced by South Africa include high levels of crime and corruption and weak economic growth. The United Nations Office on Drugs and Crime (2013) reports that crime is an important issue in South Africa.The country has halved its murder rate, but still remains one of the most violent countries in the world for homicide. Corruption in public and private establishments is growing in South Africa. The Corruption Perception Index (2013) published by Transparency International ranks South Africa $72^{\text {nd }}$ position out of 177 countries with a score of 42 out of 100 (Transparency International, 2014). According to the Organisation for Economic Cooperation and Development (2013), South Africa's current economic environment is characterised by low growth rates, high unemployment, high inflation rates and volatile exchange rates.

Small and medium enterprises (SMEs) are expected to be an important vehicle to address the challenges of job creation, sustainable economic growth, equitable distribution of income and the overall stimulation of economic development in South Africa (FinScope, 2010). According to a study by Asian Development Bank and the Organisation 
for Economic Cooperation and Development (2014), SMEs comprise the overwhelming majority of firms in almost all countries, and contribute to at least two thirds of total employment. SMEs drive economic growth through their contribution to innovation and productivity growth. The National Small Business Act of South Africa of 1996, as amended in 2003, describes an SME as "a separate and distinct entity including cooperative enterprises and non-governmental organisations managed by one owner or more, including its branches or subsidiaries if any is predominantly carried out in any sector or sub-sector of the economy mentioned in the schedule of size standards, and can be classified as an SME by satisfying the criteria mentioned in the schedule of size standards". The criteria include turnover, number of employees and the gross asset total (Government Gazette of the Republic of South Africa, 2003).

\section{Objective of the Study}

South Africa faces some development challenges. These include high levels of unemployment, poverty, income inequality and crime. The objective of the study is to examine the critical role that SMEs play in alleviating some of the development challenges facing South Africa.

\section{Literature Review}

\subsection{Definition of development}

Thomas (2004) points out that development is a concept which is contested both theoretically and politically. Development is complex and ambiguous. Development can be termed as a process of structural societal change. Bellù (2011) defines development as "event constituting a new stage in a changing situation or the process of change per se". Development is implicitly intended as something positive or desirable. Development when referred to a society typically means improvement in the general situation of the system, or in some of its constituent elements. Thus, development is a multi-dimensional concept in its nature and includes economic development, human development, territorial development and sustainable development. William (2003) remarks that development (especially economic development) is concerned with how to modernise backward economies. Nafzinger (2006) argues that development is a social phenomenon that involves more than increasing per capita output (i.e. economic growth). Development is about eliminating poverty, unemployment and inequality as well. Todaro and Smith (2009) agree that development involves not only economic growth but also reducing deprivation and broadening choice. Deprivation represents a multi-dimensional view of poverty that includes hunger, illiteracy, illness and poor health, powerlessness, voicelessness, insecurity, humiliation, and a lack of access to basic infrastructure. Development embodies elements such as political freedoms, economic facilities and social opportunities.

Todaro and Smith (2009) assert that development should answer the following questions (1) What has been happening to poverty? (2) What has been happening to unemployment? (3) What has been happening to inequality? If all three of these have become less severe, then beyond doubt, this has been a period of development for the country concerned. If one or two of these central problems have been growing worse, especially if all three have, it would be strange to call the result development, even if per capita income has soared. Economic development is the development of the economic wealth of countries or regions for the well-being of their inhabitants. It is the process by which a nation improves the economic, political, and social well-being of its people. From a policy perspective, economic development can be defined as efforts that seek to improve the economic well-being and the quality of life of a community by creating and/or retaining jobs and supporting or growing incomes and the tax base (TeVelde, 2001). Contemporary economists have expanded the definition of development to include sustainable development. According to Valente (2005), sustainable development is an emerging approach to development that combines aspects of traditional economic development with elements of environmental and social policy. Sustainable development reflects a process that meets the needs of the present without compromising the ability of future generations to meet their own needs.

\subsection{The development challenges facing South Africa}

The World Bank (2014) points out that within the context of development, countries can be broadly classified into developed and developing. South Africa can be characterised as a developing country. However, South Africa has a twotiered economy; one rivalling other developed countries and the other with only the most basic infrastructure. South Africa is regarded as a productive and industrialised economy that exhibits many characteristics associated with developing countries such as an uneven distribution of wealth and high levels of poverty and unemployment. According to the World 
Bank (2013), three of the major development challenges facing South Africa are high levels of poverty, income inequality and unemployment. The government of South Africa agrees that solving these three development challenges is a primary objective. Pahad (2008) points out that "South Africa's social-economic goals are clear; reduce inequalities, reduce wealth and asset gaps between rich and poor, halve unemployment by 2014 and meet the Millennium Development Goals. One of the ways of meeting the challenges is ensuring the development of the SME sector".

\subsubsection{The Poverty challenge}

According to the Studies in Poverty and Inequality Institute (2014), there is no general definition of the term poverty. Poverty is a contested concept and it is contested with good reason. Hulme and Shepherd (2003) and Akindola (2009) note that despite the fact that there is no general definition of poverty, one important thread in poverty discourse is the notion of material lack, especially the lack of resources necessary for survival. At their crudest, poverty studies and definitions have resorted to identifying what goods human beings would require to prevent them from dying. Dignity is also another important thread. People who are able to survive may still be considered poor if survival requires them to give up their self-respect, or if they are not able to fulfil their minimal social obligations in society. Statistics South Africa (2014) points out that poverty level has declined in the South Africa since 2006. However, poverty level is still relatively high despite the fact that the number of people living below the poverty line has dropped. Table 1 depicts the poverty levels in South Africa, two African countries (Uganda and Nigeria) and the four other countries apart from South Africa that constitute BRICS.

Table 1: Poverty levels in South Africa and some selected countries

\begin{tabular}{|c|c|}
\hline Country & Poverty level \% \\
\hline Brazil & $6.1(2009)$ \\
\hline China & $11.8(2009)$ \\
\hline India & $32.7(2009)$ \\
\hline Russia & Not available \\
\hline South Africa & $13.8(2009)$ \\
\hline Uganda & $38(2009)$ \\
\hline Nigeria & $68(2010)$ \\
\hline
\end{tabular}

Source: Adapted from Poverty and Equity data World Bank (2014)

Table 1 shows that poverty levels (2009 and 2010 figures) are lower in South Africa compared to most Sub-Sahara Africa countries. Landsberg and Moore (2013) point out that South Africa joined the BRIC (Brazil, Russia, India and China) group at the end of 2010, and the name changed from BRIC to BRICS (The S stands for South Africa). This is an association of some of the most important emerging economies in the world. Table 1 shows that South Africa's poverty level is higher than that of Brazil and China but lower than that of India.

Sachs (2005) notes that the elimination of poverty remains one of the key objectives of governments worldwide and that poverty can be ended before 2025. Beck et al. (2005) suggest that one of the ways to reduce poverty is the development of the SME sector. According to the Parliament of the Republic of South Africa (2005), the government of South Africa identifies SMEs as a key to poverty alleviation, income equality, employment and sustainable economic growth. "The stimulation of SMEs must be seen as part of an integrated strategy to take this economy onto a higher road - one in which our economy is diversified, poverty is reduced, productivity is enhanced, investment is stimulated and entrepreneurship flourishes". The New Partnership for Africa's Development (2012) agrees that "SMEs offer significant prospect for increased employment, poverty alleviation, increased utilisation of Africa's productive and intellectual resources, improved tax base for government revenues and low-cost accessible investment opportunities for local populations".

The International Labour Organisation (2008) asserts that a vibrant SME sector improves productivity, promotes economic growth and increases opportunities for the poor. SMEs tend to employ poor and low-income workers. SMEs are sometimes the only source of employment in poor regions and rural areas. Self-employment is the only source of income for many poor. SMEs play a particularly important role in developing countries where poverty is most severe. According to the Organisation for Economic Cooperation and Development (2014), SMEs are crucial for forging new paths to more sustainable and inclusive growth because of their role in developing and diffusing innovation and providing 
employment. Tan (2003) compares the poverty reduction ability of SMEs and foreign aid. Tan (2003) argues that traditionally, development agencies have focused on providing aid to poor countries as a means of tackling poverty. While aid and disaster relief (humanitarian assistance) remain important in helping the developing world, governments and NGOs have recognised that aid alone is insufficient to alleviate the problem of endemic poverty. Likewise, development projects have an important role to play in education, caring for the vulnerable, skills training and community-based handicraft and subsistence-farming. However, because they are not self-sustaining projects, many such projects run out of support after a while. One of the few success stories in poverty reduction in the past 30 years has been the development of the micro-finance institutions (MFIs) that provide small uncollateralised loans to poor entrepreneurs to start small business.

\subsubsection{Income inequality challenge}

Triegaardt, (2006) remarks that despite some economic gains, huge disparities remain in South Africa. Although there is evidence to suggest that income inequality has narrowed somewhat over the last decade, South Africa's income inequality remains one of the highest in the world. Inequality has two equally important meanings. In a sociological sense, inequality is a characteristic of social power relations. Inequality is said to be present if membership of different social groups is linked to highly differential power relations. In this sense, inequality is closely linked to the notion of social exclusion, in that unequal power relations may be linked to differential access to political or socio-economic rights. Inequality can also be linked to the existence of deeply institutionalised social hierarchies, as between masters and servants in slave and post-slave societies, or in societies where class identity and race are closely linked. In a much narrower quantitative and economic sense, inequality can refer to an imbalance in the distribution of particular resources, such as income, in a specific population. In a well-resourced country, the existence of poverty can be said to be a manifestation of inequality (Studies in Poverty and Inequality Institute, 2014).

Table 2: Gini index of South Africa and some selected countries

\begin{tabular}{|c|c|}
\hline Country & Gini index \\
\hline Brazil & $55(2009)$ \\
\hline China & $42(2009)$ \\
\hline India & $34(2010)$ \\
\hline Russia & $40(2009)$ \\
\hline South Africa & $63(2009)$ \\
\hline Nigeria & $48.8(2010)$ \\
\hline Uganda & $44.3(2009)$ \\
\hline
\end{tabular}

Adapted from Distribution of Income data World Bank (2014)

World Bank (2014) points out that the Gini index measures the extent to which the distribution of income or consumption expenditure among individuals or households within an economy deviates from a perfectly equal distribution. A Gini index of 0 represents perfect equality, while an index of 100 implies perfect inequality. Table 2 shows that income inequality (2009 and 2010 figures) is higher in South Africa compared to the selected African countries. In addition, income inequality is higher in South Africa compared to the four other members of BRICS. According to Statistics South Africa (2014), while the poverty situation has seen some improvement, inequality however remains a challenge. Income inequality in South Africa is one of the highest in the world. Mnenwa and Maliti (2008) study the role of SMEs in Tanzania and find that SMEs help to reduce income inequality. According to Liu and Yu (2008), the promoting the development of SMEs in rural areas and economically underdeveloped regions could help to reduce urban-rural migration and regional income inequality. SMEs are more labour intensive than large firms and have narrower wage differentials across workers. Hence, as the SME sector expands relative to the large firm sector of the economy, the share of labour in national income should rises, inequality among wage earners decreases, and overall income inequality decreases.

\subsubsection{The unemployment challenge}

In South Africa, there are two main definitions of unemployment; the narrow and the broad definition. The narrow definition counts as unemployed all jobless persons who want work and who are searching for work. These people are referred to as the searching unemployed. The broad definition drops the search criterion and counts as unemployed all 
jobless persons who report that they want work even if they did not search in the reference period. In other words, the broad definition includes both the searching and the non-searching unemployed. Government agencies such as Statistics South Africa and the South African Reserve Bank adopted the narrow concept as their official definition of unemployment in 1998 (Kingdon and Knight, 2006). According to the National Labour and Economic Development Institute (2008), unemployment is extremely high in South Africa and it is seen as one of the most pressing socio-political problems facing the government. South Africa has one of the most interesting labour markets in the world. Its sharp segmentation, high unemployment and low non-farm informal sector employment make it an international outlier. The developments in the labour market may hold the key to South Africa's prosperity or penury. It is from the labour market that the benefits of incomes can flow to reduce poverty or the threat to social and political stability from growing unemployment and underemployment could emerge. The current employment situation in South Africa is that the economy is unable to absorb productively all current labour force or all the increment to the labour force. The narrow unemployment rate at 25.2\% according to Statistics South Africa (2014) is one of the highest in the world. Herrington and Kew (2014) note that 4.6 million people are looking for and cannot find jobs and another 2.3 million people have given up lookingfor work. This implies that which means that approximately 7 million South Africans are unemployed representing $36 \%$ (broad) of the labour force.

Table 3: Unemployment rate in South Africa and some selected countries

\begin{tabular}{|c|c|}
\hline Country & Unemployment rate (\%) \\
\hline Brazil & $6.9(2012)$ \\
\hline South Africa & $25.0(2012)$ \\
\hline India & $3.4(2012)$ \\
\hline China & $4.5(2012)$ \\
\hline Russia & $5.5(2012)$ \\
\hline Uganda & $4.2(2012)$ \\
\hline Nigeria & $7.5(2012)$ \\
\hline & \\
\hline
\end{tabular}

Unemployment data World Bank (2014)

Table 3 shows that unemployment rate (2012 figures) is much higher in South Africa compared to the selected African countries and the four other members of BRICS. The government of South Africa expects SMEs to be the engine of employment creation. It is estimated that SMEs contribute $50 \%$ of gross domestic product and provide employment to about $60 \%$ of the labour force in South Africa. SMEs are considered an important driver for reducing unemployment in South Africa (BankSeta, 2014). According to Neumark et al. (2008), it was the employment generating potentials of small firms in the United States of America as pointed out in the Birch Report of 1979 that stimulated interest in the study of SMEs worldwide. The report found that contrary to the popular belief that large firms created most new jobs, it was primarily the SMEs that drove the job creating efforts, and at a faster rate. However, the contribution of SMEs towards alleviating the development challenges faced by South Africa depends on the level of entrepreneurship.

\section{Level of Entrepreneurship in South Africa}

Aaltonen and Akola (2014) point out that small business is often used as a synonym for entrepreneurship. The contribution of the small business sector cannot be sustained without the creation of new SMEs. According to Maas and Herrington (2006), new SMEs are seen as a significant component of the solution to South Africa's development issues. New business creation is fundamental to the growth of the South African economy and its future socio-political stability. The creation and sustainability of new SMEs are vital to the economic prosperity of South Africa. Without the creation of new SMEs, South Africa risks economic stagnation.

The perception of entrepreneurial opportunities reflects the percentage of individuals who believe there are opportunities to start a business in the area they live in. Perceived capabilities reflect the percentages of individuals who believe they have the required skills, knowledge and experience to start a new business. The perception of opportunities and the perception of capabilities have increased year on year from 2001 to 2013 by $92 \%$ and $40.5 \%$ in South Africa (Herrington and Kew, 2014). However, the two are still lower than for Nigeria and Uganda. In addition, compared to other BRICS countries, perceived opportunity and capability are lower in South Africa than in Brazil and India but higher than in Russia and China. The relatively low level of perceived capabilities can negatively impact on new venture creation in 
South Africa.

The total early stage entrepreneurial activity (TEA) measures the level of early-stage entrepreneurs who are in the process of starting or who have just started a business. This could be nascent entrepreneurs (who have not paid salaries or wagesfor more than three months) or new entrepreneurs (who have moved beyond the nascent stage and have paid salaries and wages for more than three months and less than 42 months). The total early-stage entrepreneurship level of South Africa at $10.6 \%$ remains significantly below that of other Sub-Saharan African countries included in the Global Entrepreneurship Monitor survey. However, there has been some improvement in South Africa's TEA from a low 4.3\% in 2003 to $10.6 \%$ in 2013. South Africa's position in TEA ranking in 2003 was 35th out of 68 countries with one position above the median position (Herrington and Kew, 2014). Table 4 compares the levels of perceived opportunity, capability, TEA, established and discontinuance business rates of South Africa, two African countries and the four other BRICS countries. The TEA rate is lower in South Africa than in Brazil and China but higher than in Russia and India. The established business rate for South Africa is 2.9 , while the discontinuance rate is 4.9. This implies that there is a net loss of small businesses. In BRICS, South Africa not only has the lowest rate of established rate but also the highest rate of discontinuance. The low rate of business establishment and the high rate of discontinuance paint a bleak picture of the potential of SMEs to contribute meaningfully to job creation, economic growth and more equal income distribution in South Africa.

Table 4 perceived opportunity, capability, TEA, established business rate and discontinuance in South Africa and some selected countries

\begin{tabular}{|c|c|c|c|c|c|}
\hline Country & $\begin{array}{c}\text { Perceived } \\
\text { opportunity }\end{array}$ & $\begin{array}{c}\text { Perceived } \\
\text { capability }\end{array}$ & TEA & $\begin{array}{c}\text { Established business } \\
\text { rate }\end{array}$ & $\begin{array}{c}\text { Discontinuation of } \\
\text { business rate }\end{array}$ \\
\hline Brazil & 50.9 & 52.6 & 17.3 & 15.4 & 4.7 \\
\hline China & 33.0 & 36.2 & 14 & 11 & 2.7 \\
\hline India & 41.4 & 55.7 & 9.9 & 10.5 & 1.5 \\
\hline Russia & 18.2 & 28.2 & 5.8 & 3.4 & 1.6 \\
\hline South Africa & 37.9 & 42.7 & 10.6 & 2.9 & 4.9 \\
\hline Nigeria & 84.7 & 87.0 & 39.9 & 17.5 & 7.9 \\
\hline Uganda & 81.1 & 83.8 & 25.2 & 36.1 & 20.1 \\
\hline
\end{tabular}

Adapted from Amoros and Bosma: Global Entrepreneurship Monitor (2014)

\section{Conclusion}

South Africa faces some development challenges. These include high levels of unemployment, poverty, income inequality, crime and corruption. The income inequality level and unemployment rate of South Africa are one of the highest in the world. The objective of the study is to examine the critical role that SMEs play in alleviating some of the development challenges facing South Africa. Development can be termed as a process of structural societal change and is about eliminating poverty, inequality and unemployment. SMEs are expected to be an important vehicle to address the challenges of job creation, sustainable economic growth, equitable distribution of income and the overall stimulation of economic development in South Africa. However, the TEA rate is still relatively low in South Africa despite some improvement since 2013. In addition, South Africa has a relatively low business establishment rate and a high discontinuance rate. This implies that there is a net loss of small businesses. Although the perception of opportunities and the perception of capabilities have increased year on year from 2001 to 2013, however, the two are still relatively lower than for Nigeria and Uganda. In addition, compared to other BRICS countries, perceived opportunity and capability are lower in South Africa than in Brazil and India but higher than in Russia and China. These factors may negatively impact on the ability of SMEs to help in alleviating the development challenges facing South Africa. Policy measures to improve the low rate of business establishment and reduce the high rate of discontinuance are of critical and urgent importance in South Africa.

\section{References}

Aaltonen, Satu, Akola, Elisa (2014), Lack of trust: the main obstacle for immigrant entrepreneurship? [Online] Available: http://pyk2.aalto.fi/ncsb2012/Aaltonen.pdf (March 15, 2014)

Akindola, R.P. (2009). Towards a definition of poverty.Poor people's perspectives and implications for poverty reduction. Journal of Developing Societies, 25: 121-150

Amorós, Jose, Bosma, Niels, (2014), Global entrepreneurship monitor 2013 global report. [Online] Available: 
http://www.gemconsortium.org/docs/download/3106 9July 20 (July 15, 2014).

Asian Development Bank and the Organisation for Economic Cooperation and Development (2014), ADB-OECD Study on Enhancing Financial Accessibility for SMEs: Lessons from Recent Crises [Online] Available: http://www.adb.org/publications/adb-oecdstudy-enhancing-financial-accessibility-smes-lessons-recent-crises (June 5, 2014)

BankSeta (2014), Small and medium enterprises. [Online] Available: http://www.bankseta.org.za/downloads/Small_and_Micro_ Enterprises_Brochure.pdf (May 5, 2014)

Beck, T., Levine, $\bar{R}_{\text {., }}$ \& Demirguc-Kunt A. (2005). SMEs, growth and poverty, cross-country evidence. Journal of Economic Growth, 10(1): 197-227.

Bellù, Lorenzo, (2011), Development Paradigms A (Reasoned) Review of Prevailing Visions. [Online] Available: http://wwww.fao.org/docs /up/easypol/882/defining_development_paradigms_102en.pdf(July 10, 2014)

FinScope (2010), South Africa small business survey [Önline] Available: http://www.btrust.org.za/downloads/0_nsbs_finscope_small_ business_survey_final_report_march_2011.pdf(June 5, 2014)

Global risks (2014), World Economic Forum [Online] Available: http://www3.weforum.org/docs/WEF_GlobalRisks_Report_2014.pdf (March 15, 2014)

Government Gazette of the Republic of South Africa. (2003), National Small Business Amendment Act.[Online] Available: http://www.info.gov.za/gazette/acts/2003/a26-03.pdf (May 18, 2014)

Herrington, Mike, Kew, Jacqui (2014), GEM South Africa 2013 report. [On-line] Available: http://www.gemconsortium.org/ docs/3336/gem-south-africa-2013-report (July 10, 2014)

Hulme, D., \& Shepherd, A. (2003). Conceptualizing chronic poverty. World Development, 31(3): 403-423

International Labour Organisation. (2008), Micro and small enterprise development and poverty alleviation. [Online]. Available: http://www.lo.org./asia/whatwedo/publications (December 15, 2012)

Kingdon, G., Knight, J. (2006). Unemployment in South Africa, 1995-2003: Causes, problems and policies. Journal of African Economies, 16(5): 288-304.

Landsberg, C., \& Moore, C. (2013). BRICS, South-South cooperation and the Durban summit: What's in it for South Africa? Portuguese Journal of International Affairs, 7(spring/summer) 1-14

Liu, M., Yu, J. (2008). Financial structure, development of small and medium enterprises and income distribution in the People's Republic of China. Asian Development Review, 25(1): 137-155.

Maas, Gideon, Herrington, Mike. (2006). Global entrepreneurship monitor South African report. [Online] Available: http://www.gemconsortium.org/document.aspx?id756 (September 6, 2013).

Mnenwa, R., \& Maliti, E. (2008). The role of small business poverty allocation: the case of Dar es salaam, Tanzania. Dar essalaam: MkukinaNyota Publishers.

Nafzinger, E.W. (2006). Economic development. (4thed.).Cambridge: University Press.

National Labour and Economic Development Institute. (2008), Poverty and unemployment in South Africa. [Online] Available: http://www.naledi.org.za (May 15, 2013)

New Partnership for Africa's Development. (2012). Market access initiative. [Online]. Available: http://www.unido.org.hleadmin/ import/11340 (June 10, 2012)

Neumark, David, Wall, Brandon, Zhang, Junfu (2008), Do Small Businesses Create More Jobs? New Evidence for the United States from the National Establishment Time Series.[Online]. Available: http://ftp.iza.org/dp3888.pdf (May 5, 2014).

Organisation for Economic Cooperation and Development (2013), OECD economic surveys South Africa. [Online] Available: http://www.oecd.org/eco/surveys/South\%20Africa\%202013\%200verview\%20FINAL.pdf(June 5, 2014)

Organisation for Economic Co-operation and Development (2014). Financing SMEs and Entrepreneurs (2014).An OECD Scoreboard. [Online] Available: http://www.oecd.org/industry/smes/ (May 28, 2014)

Pahad, Aziz, (2008). South-South cooperation and poverty reduction. [Online] Available http://www.dfa.gov.za/docs/speeches 12007/paha0130.htm (July 26, 2011)

Parliament of the Republic of South Africa. (2005), The white paper on national strategy for the development. [Online] Available: http://www.info.gov.za/whitepaper/1995/smallbus.htm ( October 17, 2013)

Sachs, J.D. 2005. The end of poverty: the economic possibilities of our time. (1sted.). New York: Penguin Books.

Shisana, O., Rice, K., Zungu, N., \& Zuma K (2010). Gender and Poverty in South Africa in the Era of HIV/AIDS: A Quantitative Study. Journal of Women's Health, 19(1): 39-46

Statistics South Africa (2010), Social profile of South Africa, 2002-2009. [Online] Available http://www.statssa.gov.za/publications/ Report-03-19-00/Report-03-19-002009.pdf (March 18, 2014)

Statistics South Africa (2014), Quarterly Labour Force Survey. [Online] Available: http://beta2.statssa.gov.za (June 15, 2014).

Statistics South Africa (2014), Poverty trends in South Africa. . [Online] Available: http://beta2.statssa.gov.za/?p=2591 (June 5, 2014)

Studies in Poverty and Inequality Institute. (2014), Definition of Poverty. [Online]. Available: http://www.spii.org.za (May 15, 2014)

Tan, A. (2003). Aid and performance.Journal of Development Studies, 38(3): 80-95.

TeVelde, Willem, (2001), Foreign direct investment and development: an historical perspective. [Online]. Available: http://www.scribd.com/doc/193251339/Foreign-Direct-Investment-and-Development-An-Historical-Perspective (July 1, 2014)

Thomas, Alan, (2004). The Study of Development. Paper prepared for DSA Annual Conference, 6 November, Church House, London Todaro, M.P., Smith, S.C. (2009). Economic development (11 thed.) New York: Adison Welsley.

Transparency International (2014), The Corruption Perception Index 2013. Online] Available: http://cpi.transparency.org/cpi2013/(June 
10, 2014)

Triegaardt, Jean, (2006), Reflection on poverty and inequality in South Africa. [Online]. Available: http://www.sarpn.org.za/ countrypovertypapers/cppsouthafrica.php (March 5, 2014)

United Nations Office on Drugs and Crime (2013), Global Study on homicide. [Online] Available: http://www.unodc.org/742DE067-471A459E-9152- (May 10, 2014)

Valente, S. (2005). Sustainable development renewal resources: a technological progress. Environmental and Resources Economics, 30(1): 115-125.

William, G. (2003). Studying development and explaining policies. Oxford Development Studies, 31(1): 37-58.

World Bank (2013), South Africa economic update- focus on financial inclusion. [Online] Available: http://www.worldbank.org/ content/dam/Worldbank/document/Africa/South\%20Africa/Report/south-africa-economic-update-2013.05.pdf (May 5, 2014)

World Bank (2014), Countries and economies. [Online] Available: http://data.worldbank.org/country/ (June 3, 2014)

World Bank (2014), Poverty \& Equity.[Online] Available: http://povertydata.worldbank.org/poverty/country/RUS(June 5, 2014)

World Bank, (2014), World Development Indicators:Distribution of income or consumption. [Online] Available: http://data.worldbank. org/indicator/SI.POV.GINI_(June 5, 2014)

World Bank (2014), Unemployment, total (\% of total labour force) (modelled ILO estimate.[Online] Available: http://data.worldbank. org/indicator/SL.UEM.TOTL.ZS_(June 5, 2014) 